\title{
AUTHOR INDEX 1994
}

Beaird, C.: See Ponthieu, L.D., 37

Behrmann, M., Schepis, M.: Assistive Technology Assessment: Multiple Case Study Review With Physical Approaches With Students With Physical Therapy Disabilities During the Transition From School to Work, 202

Belcher, R.G.: See Datlow Smith, M., 10, 52, 66

Belcher, R.G., Datlow Smith, M.: Coworker Attitudes Toward Employees With Autism, 29

Blanck, P.D.: Empirical Study of the Americans With Disabilities Act (1990-1993), 211

Boone, R.S.: See Wolfe, P.S., 285

Brackett, J.D.: See Mcpherson, A., 131

Browder, D.M.: See Rucker, R.E., 255

Buggey, T.: See Wolfe, P.S., 285

Button, C., Wobschall, R.: The Americans With Disabilities Act and Assistive Technology, 196

Campbell, D.: See Curtis, B., 192

Clements, C.: See West, M.D., 265

Curtis, B., Campbell, D.: Business Talks Frankly About the Americans With Disabilities Act, 192

Datlow Smith, M.: Increasing Work Productivity of Employees Disabled by Autism, 60

Datlow Smith, M.: Introduction, 2

Datlow Smith, M.: See Belcher, R.G., 29

Datlow Smith, M., Belcher, R.G.: Facilitated Communication and Autism: Separating Fact From Fiction, 66

Datlow Smith, M., Belcher, R.G.: Factors Influencing Integration of Employees With Autism, 52

Datlow Smith, M., Belcher, R.G., Juhrs, P.D., Nabors, K.: Where People With Autism Work, 10

Davis, S.: A Status Report to the Nation on Inclusion in Employment of People With Mental Retardation, 243

Defur, S., Evans Getzel, E., Kregel, J.: Individual Transition Plans: A Work in Progress, 139

Demoss, S.: See Minskoff, E.H., 113

Douglas, R.: The Americans With Disabilities Act After Three Years, 153

Dowler, D.L.: See Hendricks, D.J., 174

Dymond, S.: See Inge, K.J., 272

Evans Getzel, E.: See Defur, S., 139

Feheley, D.: See LaVigna, G.W., 18

Flippo, K., Green, H.: Resources for Americans With Disabilities Act Implementation: Business Accomodation Response Teams, 183

Flippo, K.F.: Introduction, 151
Fourqurean, J.M.: The Use of Follow-up Studies for Improving Transition Planning for Young Adults With Learning Disabilities, 96

Gerber, P.J., Reiff, H.B., Ginsberg, R.: Critical Incidents of Highly Successful Adults With Learning Disabilities, 105

Ginsberg, R.: See Gerber, P.J., 105

Green, H.: See Flippo, F., 183

Gregg, N.: Eligibility for Learning Disabilities Reha. bilitation Services: Operationalizing the Definition, 86

Gregg, N.: Introduction, 83

Griffin, C.: Organizational Natural Supports: the Role of Leadership in Facilitating Inclusion, 296

Hendricks, D.J., Dowler, D.L., Judy, B.: Real-Life Issues In Job Accomodation: Employers' and Employees' Perspectives, 174

Hoy, C.: Social/Emotional Characteristics of Adults With Learning Disabilities, 122

Inge, K.J., Dymond, S.: Challenging Behaviors in the Workplace: Increasing a Student's Access to Community-Based Vocational Instruction, 272

Jones, S.C.: See Ponthieu, L.D., 37

Judy, B.: See Hendricks, D.J., 174

Juhrs, P.D.: See Datlow Smith, M., 10

Kregel, J.: See Defur, S., 139

Kregel, J.: See Wehman, P., 231

Kregel, J.: See West, M.D., 308

Kregel, J., Tomiyasu, Y.: Employers' Attitudes Toward Workers With Disabilities, 165

LaVigna, G.W., Shaull, J.F., Feheley, D., Willist, J.: Managing for Quality, 18

Mcpherson, A., Brackett, J.D.: Postsecondary School Transition Issues Affecting the Vocational Rehabilitation of Young Adults With Learning Disabilities, 131

Minskoff, E.H., Demoss, S.: Workplace Social Skills and Individuals With Learning Disabilities, 113

Nabors, K.: See Datlow Smith, M., 10

Pancsofar, E.L.: Book Reviews, 77, 146, 313

Ponthieu, L.D., Jones, S.C., Williamson, C., Beaird, C.: Management Response to Disruptive Behav. iors by Employees With Developmental Disabilities, 37 
Rayfield, R.G.: See West, M.D., 265

Reiff, H.B.: See Gerber, P.J., 105

Revell, G.: See West, M.D., 308

Rucker, R.E., Browder, D.M.: Conversion From Sheltered to Integrated Employment, 255

Schepis, M.: See Behrmann, M., 202

Shaull, J.F.: See LaVigna, G.W., 18

Sullivan, R.C.: Autism: Definitions Past and Present, 4

Thornton, T.: See West, M.D., 265

Tomiyasu, Y.: See Kregel, J., 165

Turner, E.: Consumers and the Americans With Disabilities Act, 158

Unger, D.: See West, M.D., 265
Wehman, P., Kregel, J.: Toward a National Agenda for Supported Employment, 231

West, M.D.: Abstracts, 75, 312

West, M.D., Kregel, J., Revell, G.: Supported Employment (or What Passes for It) in America, 308

West, M.D., Rayfield, R.G., Clements, C., Unger, D., Thornton, T.: An Illustration of Positive Behavioral Support in the Workplace For Individuals With Severe Mental Retardation, 265

Williamson, C.: See Ponthieu, L.D., 37

Willis, T.J.: See LaVigna, G.W., 18

Wobschall, R.: See Button, C., 196

Wolfe, P.S., Boone, R.S., Buggey, T.: A Review of Business Literature Pertaining to the Americans With Disabilities Act: Who's Talking to Whom About What?, 285 